\title{
Wybrane aspekty napraw odlewów korpusów urządzeń energetycznych
}

\author{
Selected aspects of the repair \\ of cast bodies of power equipment
}

\section{Streszczenie}

Praca przedstawia analizę sposobu usuwania wad odlewniczych i wpływ wstępnego podgrzewania na jakość napawania drutem proszkowym. W artykule została przedstawiona charakterystyka ogólna materiałów używanych na odlewy korpusów ze wskazaniem na skład chemiczny oraz podstawowe właściwości mechaniczne. Wymieniono także główne cechy jakimi powinny się charakteryzować materiały użyte na odlewy oraz omówiono zabiegi obróbki cieplnej mającej wpływ na jakość naprawianych powierzchni z szczególnym uwzględnieniem zagadnień podgrzewania przed pracami naprawczymi -regeneracyjnymi. Omówiono wady powstałe w procesie odlewania jak i zasygnalizowano niezgodności spawalnicze mogące powstać $w$ trakcie prac spawalniczych. Wymienione zostały występujące wady, przyczyny ich występowania jak i sposoby, dzięki którym można ich uniknąć. Część pracy została poświęcona praktycznym zagadnieniom napraw odlewów. Omówiono główne czynności przygotowawcze przed rozpoczęciem prac spawalniczych mających istotne znaczenie na jakość prowadzonych prac. Opisano doświadczenia w zakresie żłobienia palnikiem propanowo-tlenowym wad odlewniczych w połączeniu z napawaniem powstałych ubytków przy wykorzystaniu drutu proszkowego i konsekwencji braku zastosowania podgrzewania przed żłobieniem.

Słowa kluczowe: naprawa, wady odlewnicze, drut proszkowy, podgrzewanie, żłobienie

\section{Abstract}

The paper presents an analysis of how to remove casting defects and the influence of preheating on the quality of welding flux cored wire. This article presents the general characteristics of the materials used for casting bodies with an indication of the chemical composition and the basic mechanical properties. Also highlights the main features of which should be characterized by the materials used for casting and heat treatment procedures discussed having an impact on the quality of the repaired area with particular emphasis on the heating before repair work. Defects which are discussed in the process of casting and welding signaled discrepancies that may arise during welding. These defects are present, their causes, and ways in which they can be avoided. Part of the work has been devoted to practical issues casting repairs. These are the main preparatory activities before welding which are important to the quality of the work. Experiments are described in terms of gouging torch propane-oxygen casting defects in conjunction with the resulting loss hardfacing using flux-cored wire and the consequences of non-application of heating before gouging

Keywords: repair, casting defects, cored wire, preheating, gouging

\section{Wstęp}

Turbina parowa jest nieodłączną częścią każdej klasycznej elektrowni. Na jej poprawną pracę ma wpływ wiele czynników zarówno podczas projektowania jak i montażu. Pierwszym etapem jej produkcji jest wykonanie odlewów. Odlewy te pomimo doskonalenia technologii odlewniczych nadal posiadają pewne wady, które dyskwalifikują elementy do bezpośredniego montażu.

Celem niniejszej pracy jest przedstawienie wykorzystywanych technologii do usuwania wykrytych wad odlewniczych w korpusach turbin parowych, metody te można wykorzystać także przy rewitalizacji korpusów, które przepracowały określoną liczbę godzin i wymagają kapitalnego remontu lub uległy awaryjnemu uszkodzeniu.
Do wytwarzania korpusów turbin parowych używane są staliwa, charakteryzujące się dużym skurczem odlewniczym, w zakresie od 1,6 do 2,1\%, w przypadku staliw stopowych skurcz może być większy. Wymagana temperatura odlewania to $1600 \div 1700{ }^{\circ} \mathrm{C}$. Z powodu dużej gęstopłynności i dużej jamy skurczowej formowanie odlewów staliwnych wymaga dużych nadlewów i układu wlewowego. Staliwa nisko-węglowe $(<0,2 \% C)$ i niektóre wysokostopowe odznaczają się złą lejnością. Struktura otrzymanych odlewów może zawierać takie wady jak: mikrorzadzizny, pęknięcia, pęcherze itp. Wraz ze zwiększeniem zawartości węgla lejność staliwa poprawia się tak, że odlewanie staliwa średnio- i wysokowęglowego nie powodują większych trudności, a struktura otrzymanych odlewów pozbawiona jest wad, lecz utrudniona jest jego spawalność.

Dr inż. Robert Bęczkowski, dr inż. Marek Gucwa - Politechnika Częstochowska. 
Własności mechaniczne staliw, są zależne głównie od zawartości węgla, z tym że są nieco mniejsze niż w przypadku stali, zwłaszcza plastyczność, natomiast wytrzymałość na pełzanie jest często większa. Przyczyną małej stosunkowo plastyczności staliwa jest struktura dendrytyczna, wiąże się to z segregacją C, P i pierwiastków stopowych. Wadą staliw, która wpływa na własności mechaniczne, jest silny wpływ grubości ścianki odlewu (szybkości krzepnięcia). Własności mechaniczne staliwa są poprawiane za pomocą obróbki cieplnej, takiej jak: ujednorodnienie, normalizowanie, odprężanie, a także hartowanie i odpuszczanie.

Warunki jakie powinny spełniać odlewy korpusów turbin zostały przedstawione w serii norm PN-EN 10213 Warunki techniczne dostawy odlewów staliwnych do pracy pod ciśnieniem, gdzie zawarte są informacje dotyczące składu chemicznego oraz własności mechanicznych z uwzględnieniem wymaganej obróbki cieplnej, jak i własności materiałów w podwyższonych temperaturach. Głównymi cechami, którymi muszą się charakteryzować materiały przeznaczone do pracy w powyższych warunkach są żaroodporność i żarowytrzymałość [1 $\div 3]$.

Z uwagi na charakter pracy elementów wykonanych ze stali energetycznych, oprócz określonych własności takich jak granicy plastyczności $\left(R_{e}^{t}\right)$, umownej granicy plastyczności w podwyższonej temperaturze (RP0,2) i wytrzymałości na rozciąganie $\left(R_{m}^{t}\right)$, należy wymienić parametr, pozwalający mierzyć ich przydatność do pracy w podwyższonych temperaturach. Tym parametrem jest odporność na pełzanie - czyli na powolne zwiększanie się trwałych odkształceń materiału poddanego długotrwałemu obciążeniu.

Charakteryzując zjawisko pełzania zachodzące w czasie pracy $w$ podwyższonych temperaturach, które powoduje wzrost plastyczności, co z kolei prowadzić może do trwałych odkształceń i wydłużeń elementów, wymienić można trzy parametry, od których ono zależy to: wielkość obciążenia i czas jego trwania oraz temperatura.

W przypadku staliw często wymagana jest obróbka cieplna, którą możemy podzielić na dwa etapy. Pierwszy etap - przygotowanie materiału do spawania, natomiast drugi - właściwa obróbka cieplna w postaci wyżarzania po spawaniu.

Podgrzewanie do spawania i w trakcie spawania - ma na celu:

- zmniejszenie prędkości chłodzenia i uniknięcie wystąpienia kruchych struktur hartowniczych i ewentualnych pęknięć metali i stopów przechodzących przemiany fazowe,

- ułatwienie spawania (zwiększenie szybkości, zapewnienie właściwego wtopienia) materiałów o dużym przewodnictwie cieplnym i przedmiotów grubych o dużej pojemności cieplnej,

- osuszenie obszaru złącza i usunięcie skondensowanej na powierzchni wilgoci mogącej być przyczyną porowatości lub pękania złączy,

- zmniejszenie naprężeń skurczowych i twardości w strefie wpływu ciepła.

Ponadto należy nie tylko odpowiednio podgrzać dany przedmiot, czy materiał ale także cały czas kontrolować temperaturę międzyściegową. Temperatura ta powinna być nie mniejsza niż temperatura podgrzewania wstępnego, a jej maksymalna wartość tak dobrana aby nie spowodować przegrzania złącza.

Do nagrzewania wstępnego używa się najczęściej palników propanowo-powietrznych. Innym sposobem podgrzewania przed spawaniem jak i prowadzenia obróbki cieplnej jest użycie nagrzewnic oporowych lub indukcyjnych. Dzięki nim możemy zapewnić odpowiednią temperaturę podczas prowadzenia prac spawalniczych oraz rejestrować przebieg procesu.
Zastosowanie zabiegów obróbki cieplnej po spawaniu pozwala na uzyskanie odpowiedniej struktury złącza, nadanie mu pożądanych właściwości mechanicznych, usuniecie naprężeń spawalniczych bądź własnych. Najczęściej stosowanymi zabiegami są operacje wyżarzania. Wyżarzanie dzielimy na takie, w których zachodzi przemiana alotropowa i decyduje ona o końcowej strukturze (ujednorodniające, normalizujące, zupełne, zmiękczające, izotermiczne), oraz takie, w których ona nie występuje (rekrystalizujące, odprężające, stabilizujące).

Wady odlewnicze powstałe w procesie odlewania, w celu klasyfikacji i ustalenia przyczyn powstawania zostały podzielone na pięć grup:

- wady kształtu - niedolew, uszkodzenie mechaniczne, wypchnięcie, zalewka, niedotrzymanie wymiarów, przestawienie, wypaczenie. Stwierdza się je na podstawie oględzin i pomiarów kontrolnych (rys. 1).

- wady powierzchni odlewanej - między innymi: chropowatość, zanieczyszczenia, wżarcie, pęcherze, strupy, fałdy, nadtopienie, wgniecenie, naloty itp (rys. 2).

- przerwy ciągliwości - pęknięcia, naderwanie, niespawy (rys. 3).

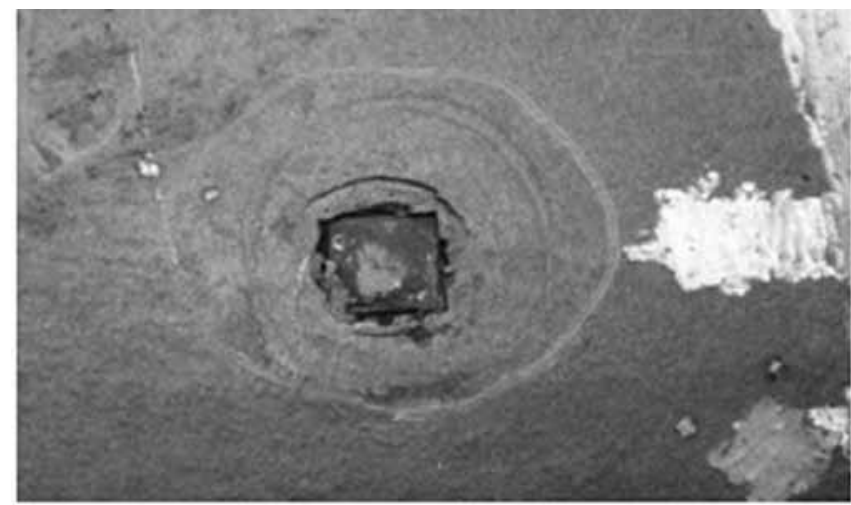

Rys. 1. Wady odlewnicze: wady kształtu

Fig. 1. Casting Defects: defects in shape

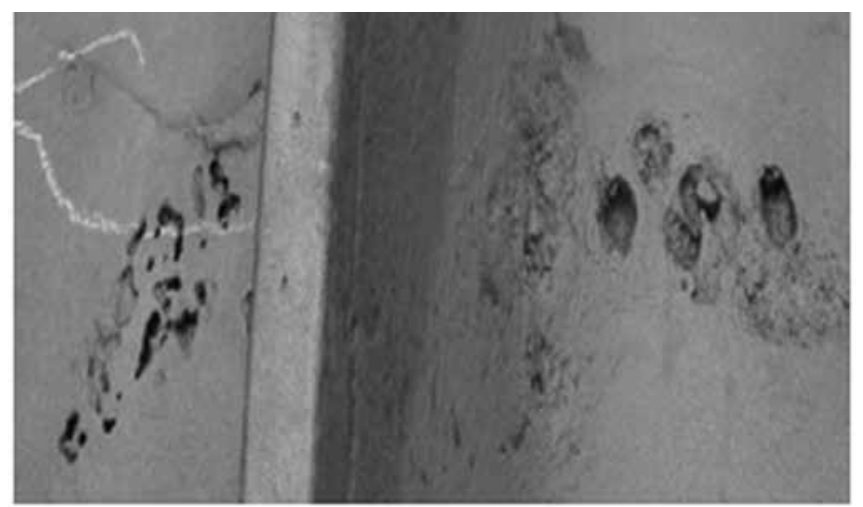

Rys. 2. Wady powierzchni odlewanej: chropowatość i pęcherze

Fig. 2. Surface defects cast: roughness and blisters

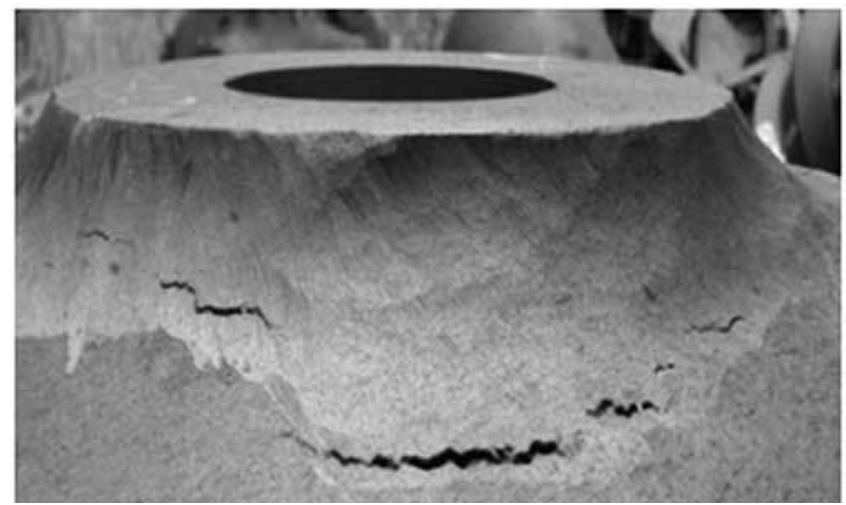

Rys. 3. Pęknięcia na zewnętrznej powierzchni odlewu

Fig. 3. Cracks on the outer surface of the casting 
- wady wewnętrzne - bąbel, pęcherz, sitowatość, jama skurczowa, zażużlenia, segregacja itp. Stwierdza się po obróbce mechanicznej przy zastosowaniu badań ultradźwiękowych oraz rentgenowskich.

- wady materiału - skład chemiczny niezgodny z warunkami technicznymi, złe własności użytkowe i wytrzymałościowe itp. Stwierdza się na podstawie analizy chemicznej, badań metalograficznych, wytrzymałościowych itp.

Najczęstszymi przyczynami występowania wad odlewniczych są: niewłaściwa konstrukcja odlewu, wadliwa konstrukcja lub wykonanie modelu, niewłaściwy materiał formierski, nieodpowiednie wykonanie formy, niewłaściwe przygotowanie stopu, źle dobrane warunki zalewania formy, niewłaściwie wykonane wybijanie, czyszczenie i wykańczanie odlewu. Naprawa odlewów wadliwych dotyczy wad kształtu, powierzchni i ciągłości. Najważniejsze sposoby naprawiania wadliwych odlewów to:

- prostowanie i usuwanie wad powierzchniowych sposobem mechanicznym - szlifowanie, ścinanie, frezowanie,

- czopowanie (wywiercenie materiału i wstawienie czopów, wkrętów),

- kitowanie - nakładanie odpowiednich kitów w miejscach wadliwych,

- nasycanie odlewów - usuwanie nieszczelności w odlewach pracujących pod ciśnieniem - stosuję się odpowiednie lakiery, ciekłe metale itp.

- metalizacja - wlewanie ciekłego metalu w miejsce wadliwe bez nadtapiania odlewu,

- spawanie - naprawa pęknięć, niedolewów, pęcherzy itp.

- lutowanie - nagrzanie odlewu palnikiem i uzupełnienie niedoboru,

- nadlewanie - uzupełnienie uszkodzonych części odlewu lub niedolewów,

- zastosowanie obróbki cieplej odlewu - uzyskanie odpo-

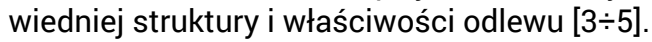

Przystępując do naprawy należy określić jego zakres. W pierwszym etapie prac to przyjecie odlewu, identyfikacja gatunku staliwa, zapoznanie się z dokumentacją techniczną, procedurami i instrukcjami dostarczonymi przez klienta oraz sporządzenie dokumentacji fotograficznej. Dokonuje się także pierwszych oględzin wizualnych, podczas których można określić, czy korpusy posiada wady powierzchni takie jak: chropowatość, wżery, pęcherze, fałdy, wgniecenia, nadtopienia, zanieczyszczenia, naloty, a także wady kształtu takie jak: uszkodzenia mechaniczne, niedolewy, niedotrzymanie wymiarów, czy pozostałości po wlewkach i żebrach (rys. 4a i 4b).

\section{Metodyka badań}

Przed przystąpieniem do prac spawalniczych konieczne jest przygotowanie korpusu do badań NDT. Odlew poddawany jest śrutowaniu oraz usuwane są pozostałości żeber i wlewków. Następnie kontrolowana jest jego geometria i poddawany jest on obróbce zgrubnej, po której następuje następna seria pomiarów kontrolnych geometrii oraz grubości ścianek (rys. 5).

Pierwszą operacją występującą podczas naprawy odlewów jest usunięcie wad odlewniczych wykrytych podczas badań nieniszczących. Wykonać to można poprzez szlifowanie, żłobienie elektrodami otulonymi lub palnikiem gazowym, każda $\mathrm{z}$ tych metod ma swoje zalety i wady. W artykule podjęto się analizy zastosowania do żłobienia palnika propanowo-tlenowego w celu usuwania wad w odlewie przeprowadzono próby technologiczne i doboru optymalnych warunków. Próby żłobienia zostały przeprowadzone na stali gatunku 13 HMF palnikiem propanowo-tlenowym. W pierwszym etapie wyżłobiono rowki o głębokości 3-4 mm w dwóch próbkach oznaczonych jako A i B. Próbka A została podgrzana wstępnie a)

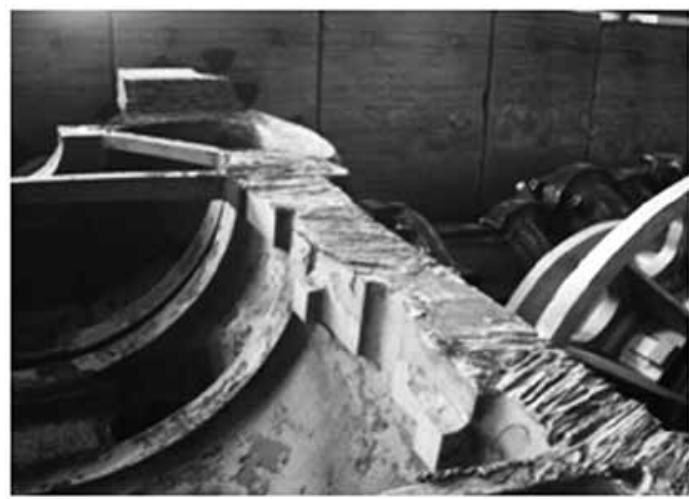

b)

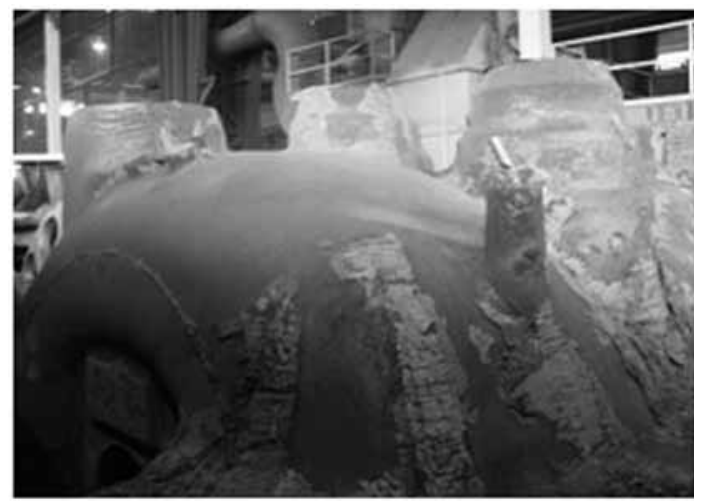

Rys. 4. Surowe, nieoczyszczone odlewy: a) powierzchnia wewnętrzna; b) zewnętrzna

Fig. 4. Raw uncleaned castings: a) the inner surface, b) outer surface

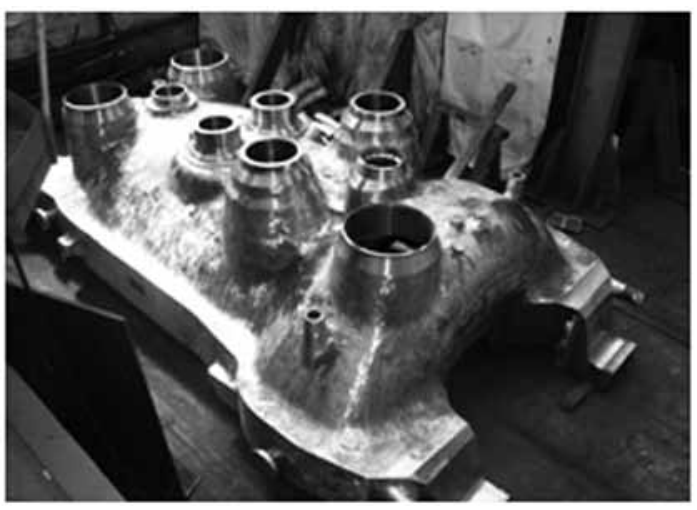

Rys. 5. Odlew oczyszczony, po obróbce zgrubnej przygotowanego do badań NDT

Fig. 5. Purified cast after roughing prepared for NDT

palnikiem propanowo-tlenowym do temperatury $150^{\circ} \mathrm{C}$. Próbka B została poddana żłobieniu bez podgrzewania wstępnego. W próbkach wyżłobione zostały rowki o kształcie zbliżonym do pokazanego na rysunku 6 . W drugim wykonano napawanie drutem proszkowym samo osłonowym [5].

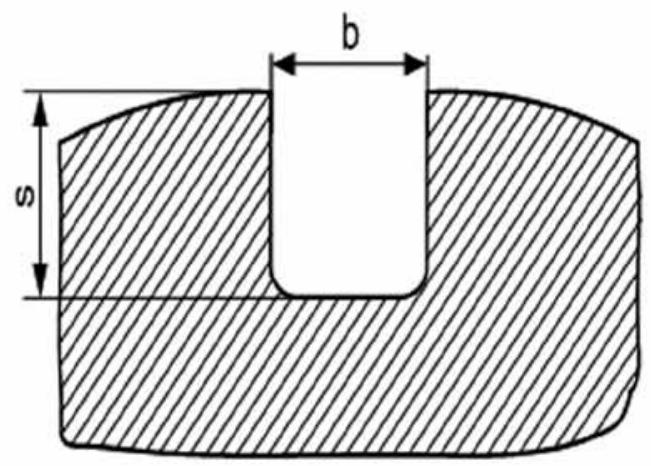

Rys. 6. Kształt wyżłobionych rowków

Fig. 6. The shape of the carved grooves 


\section{Analiza wyników}

Na zgładzie próbki A zaobserwowano szerokość strefy wpływu ciepła na poziomie 1,1 do $1,5 \mathrm{~mm}$, a dla próbki $B$ od 1,2 do 2,0 mm. Twardości Vickersa (HV10) zmierzone dla badanych próbek przedstawiono na rysunku 7.

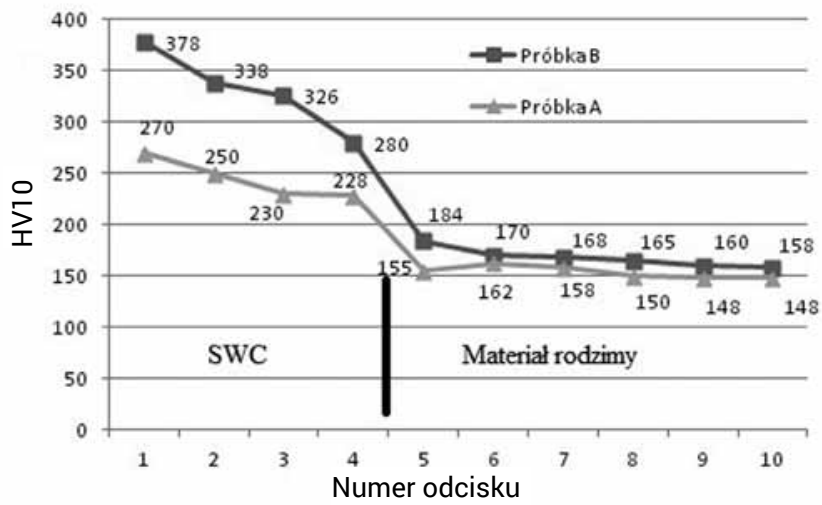

Rys. 7. Wykres twardości HV10 próbki A i B

Fig. 7. Graph of hardness HV10 sample A and B

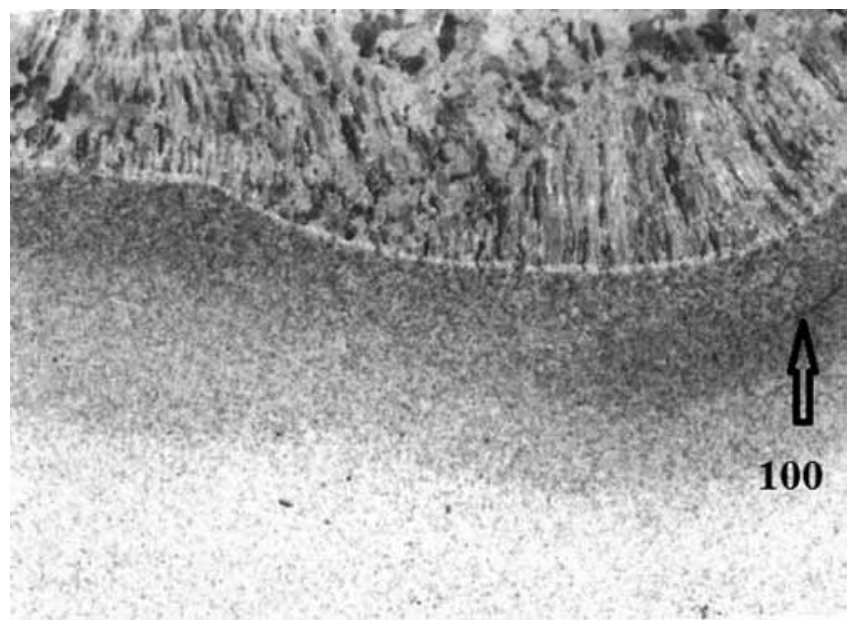

Rys. 8. Próbka B po spawaniu, struktura napoiny bainityczno-ferrytyczna, pęknięcie w SWC

Fig. 8. Sample B after welding, the weld structure ferritic-bainitic, visible crack in the $H A Z$
Na rysunkach $8 \div 10$ pokazano strukturę oraz niezgodności spawalnicze - pęknięcia 100 (PN EN ISO 6520-1) powstałe po procesie naprawy odlewu.

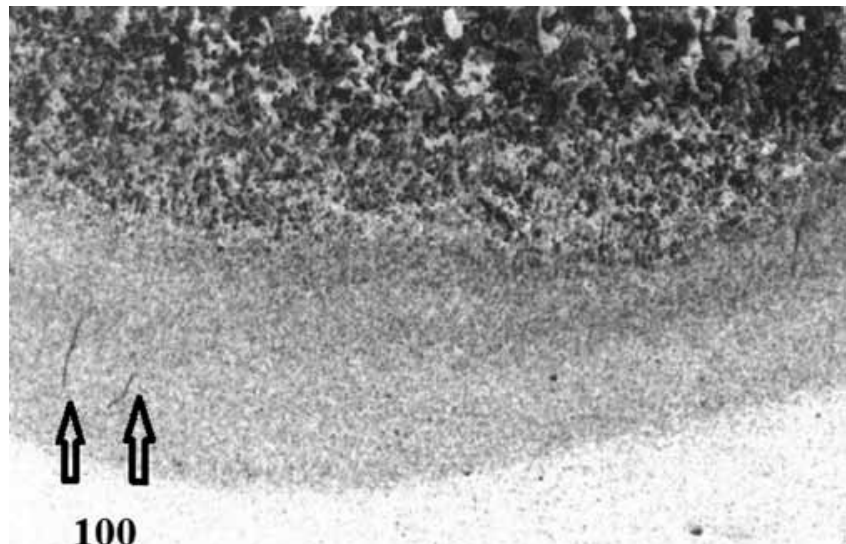

Rys. 9. Próbka B po spawaniu, struktura bainityczno-ferrytyczna - pęknięcie W SWC

Fig. 9. Sample $B$ after welding, ferritic-bainitic structure visible crack in the HAZ

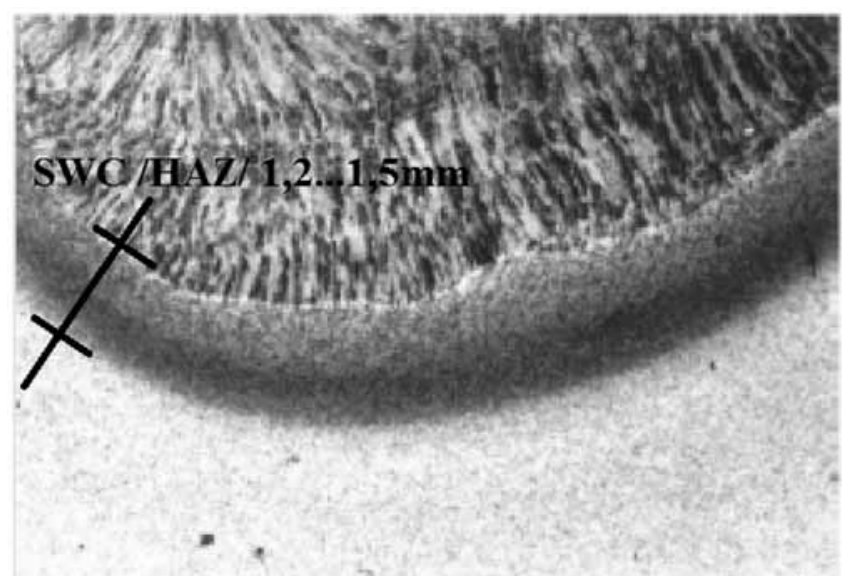

Rys. 10. Próbka A po spawaniu, struktura bainityczno-ferrytyczna Fig. 10. Sample A after welding, ferritic-bainitic structure

\section{Podsumowanie}

Żłobienie powinno odbywać się wyłącznie po uprzednim podgrzaniu wstępnym materiału rodzimego. Jak wykazał pomiar twardości próbki żłobione bez podgrzania wstępnego charakteryzowały się ok. 40\% wzrostem twardości w SWC względem materiału rodzimego oraz większą głębokością utwardzenia do $2 \mathrm{~mm}$. Doprowadziło to do powstania pęknięć w SWC podczas napawania ubytku (rys. 8 i 9).

Powierzchnie żłobione bez podgrzewania wstępnego charakteryzują się grubszą warstwą twardej, nadtopionej i zakrzepłej struktury oraz zanieczyszczeń.

Pod względem strukturalnym korzystniejsza jest struktura SWC próbek żłobionych z podgrzewaniem wstępnym. Próbki żłobione na zimno charakteryzowały się twardą strukturą martenzytyczną lub martenzytyczno-bainityczną o twardości powyżej 350HV10 (rys. 7) i przeszło dwukrotnym wzroście twardości w stosunku do materiału rodzimego.

\section{Literatura}

[1] PN EN 10027-1:2007 Systemy oznaczania stali -- Część 1: Znaki stali

[2] PN-EN 10213:2010 Odlewy staliwne do pracy pod ciśnieniem.

[3] Dobrzański L.A; Podstawy Nauki o materiałach i metaloznawstwo, WNT, Warszawa 2002.

[4] Perzyk M., S Waszkiewicz S., Kaczorowski M., Jopkiewicz A.; Odlewnictwo, WNT, Warszawa 2000

[5] Wodecki D.; Technologie naprawy odlewów korpusów oraz uzbrajania komór zaworowych turbin wielkogabarytowych wykonanych ze stali energetycznych, Politechnika Częstochowska, Częstochowa 2010 